\title{
Production and Invivo Evaluation of Bread from Wheat and Cassava Flours
}

\author{
Ameh $\mathrm{CO}^{1}$, Ochelle $\mathrm{PO}^{1 *}$ and Gbaa $\mathrm{ST}^{\mathbf{2}}$ \\ ${ }^{1}$ Department of Food Science and Technology, Federal University of Agriculture, Makurdi, Nigeria \\ ${ }^{2}$ Center for Food Technology and Research, Benue State University, Makurdi, Nigeria \\ *Corresponding Author: Ochelle PO, Department of Food Science and Technology, Federal University of Agriculture, Makurdi, Nigeria
}

Received: August 28, 2019; Published: September 04, 2019

DOI: $10.31080 /$ ASMI.2019.02.0361

\begin{abstract}
The study was carried out to investigate the effect of supplementation of $10 \%$ cassava flour on bread without compromising the nutritive value of wheat based bread. Feeding trial of Wistar-strain rats were used to evaluate the nutritional status of the $10 \%$ casssava composite bread. $100 \%$ wheat bread was used as control. The results showed that the rats fed on the control diet (6.42g) more than those fed on the $10 \%$ cassava composite bread $(5.10 \mathrm{~g})$. The weight gain of the rat fed on the composite bread was higher (3.06g) than those fed on the control diet (2.84g). Result of the protein efficiency ratio of the rats fed on the composite bread revealed higher values of (12.73) than those fed on the control diet (4.47). The plasma protein of rats fed on the control diet revealed higher value of $(60.40 \mathrm{~g} / \mathrm{ml})$ than those fed on the composite bread $(42.44 \mathrm{~g} / \mathrm{ml})$. The plasma glucose of the rats fed on the control diet was lower $(4.09 \mathrm{mmol} / \mathrm{l})$ than those of the composite bread $(6.44 \mathrm{mmol} / \mathrm{l})$. The plasma glucose of the rats fed on both diets was seen to be above the normal plasma glucose 3.12. The plasma protein of the rats fed on the composite bread was below the normal plasma protein. It can be observed from the consumption pattern table that the rats fed on both the control and composite bread had higher hyperglycemic with continuous feeding of the bread samples. It is therefore recommended that bakeries should include protein supplement in the processing of cassava composite bread.
\end{abstract}

Keywords: Wheat Flour; Cassava Flour; Rats

\section{Introduction}

In many developing countries such as Nigeria, bread consump- tion is expanding and there is an increasing dependence on imported wheat which has been found to take up much of the country's foreign exchange earnings per annum. Bread can be described as a fermented confectionary product made mainly from wheat flour, water, yeast, and salt by series of processes involving mixing, kneading, proofing, shaping and baking [1]. It is an important staple food in both developing and developed countries and constitutes one of the major sources of nutrients such as carbohydrates, protein, fibre, vitamins, and minerals in the diet of many people worldwide [2]. The consumption of bread in Nigeria is on a steady increase because it is convenient and ready to eat food normally consumed at breakfast, lunch and sometimes dinner [3]. In Nigeria, bread has become the second most widely consumed nonindigenous food after rice [4]. The rapid urbanization, increasing population and changing food habits have resulted in the preference for convenient foods such as bread, biscuits and other baked products [5,6]. Different flours from cereals (maize, rice, ssorghum and millet) and tubers rich in starch (cassava, cocoyam, sweet potato and yam) and protein rich flours (cowpea, soybean etc) have been used in bread making to partially substitute wheat flour $[7,8]$. Eriksson et al. [9] in his work, determined the maximum inclusion level of cassava flour with three different ratios of 10, 20 and 30\% composite of wheat and cassava flour for baking bread. Physical analysis of the bread from composite flour revealed decreased in the specific volume of the bread made from wheat and cassava flours with increasing proportion of cassava flour with $10 \%$ casssava flour substitution having the highest specific volume similar to the one from $100 \%$ wheat bread. Ochelle et al. [10] evaluated the effect of water yam and soybean flours addition on the quality of wheat based bread, chemical analysis revealed increase in all the nutritional parameters of the bread. Nigeria grows staples other than wheat that can be used for bread making. One of such staples is the starchy tuber cassava.

Cassava is one of the most important crops in Africa. Nigeria is the leading producer globally. It's addition in making bread has been suggested as $10 \%$ or $20 \%$ by some researchers and $40 \%$ by 
Nigeria government. However, there is evidence in favour of producing bread from composite flour of 90:10 wheat to cassava flour as well as 80:20 due to some physical parameters which compared favorably with that of $100 \%$ wheat flour. Although, bread made from different composite flour wheat and cassava has been advocated, their health, especially nutritional implication, has not been investigated. Cassavas are high in cyanogenic glycosides content as well as antinutritional factors that could be detrimental to health. The bitter and sweet cassavas are the two varieties of cassava based on the cyanogenic glycosides of their root [11]. Those with high cyanide content are called bitter cassava while those with little amount of cyanide are called sweet cassava [12]. Nutritionally, cassava is the major source of dietary energy for low income consumers in many parts of tropical Africa [13]. One hundred grams of cassava roots contains $62.5 \mathrm{~g}$ of water, $34.7 \mathrm{~g}$ of starch, $1.2 \mathrm{~g}$ of protein, $0.3 \mathrm{~g}$ of fat, $33 \mathrm{~g}$ of calcium and $36 \mathrm{mg}$ of vitamin C [14].

The objective of this study was to evaluate the nutritional implication of $10 \%$ cassava supplementation to wheat based bread using in vivo assay.

\section{Materials and Methods}

The raw materials for bread production were wheat (Triticum aestivum) and cassava (Manihot esculenta Creantz). The equipment used for the study were obtained from the Department of Food Science and Technology and the Department of Biochemistry, Federal University of Agriculture, Makurdi, Nigeria. The Randox reagent was purchased reagent was purchased from a distributor at Onitsha, Anambara, Nigeria.

\section{Animal Experimentation}

A total of 20 male and female weanling albino rats, 21-28 days old were obtained from the Animal House of the Biochemistry Department. The rats were distributed randomly into two different groups of ten animals each and transferred into a wooden cage with wire gauze at the top [15]. They were now allowed to acclimatize with growers mash for six days under normal temperature before the commencement of the experiment. The rats in the first group were fed on bread made from $90 \%$ wheat and $10 \%$ cassava flour. Water was provided adlibitum, $8 \mathrm{~g}$ of the sample was initially provided to each rat daily but was later increased to $10 \mathrm{~g}, 12 \mathrm{~g}$ as feeding increases. The residue was weighed and removed before the next feeding. Daily records of food intake and weekly records of weight gained were maintained. The experiment was terminated at the end of two weeks.
Collection of blood sample for determination of total protein and glucose concentration

The rats were cut by the tails. Blood samples were collected into vials containing fluoride oxalate by pressing the tail. The blood was later centrifuged for 15 minutes at 4000rpm using an 80-2 Electronic Centrifuge. The clear supernatant (plasma) was used for the estimation of total protein and glucose concentrations.

\section{Determination of total protein}

$0.5 \mathrm{ml}$ of the samples were taken in labeled test tubes, and $2 \mathrm{ml}$ of colour reagent was added to it. In preparing the blank, $2 \mathrm{ml}$ of colour reagent was taken in another test tube labeled blank and 50ul of distilled water was added to it. These test tubes were incubated for 10 minutes at a temperature of $37^{\circ} \mathrm{C}$. The samples were transferred from the test tubes into the cuvette and placed in auto colorimeter set at $54 \mathrm{onm}$ and their absorbance readings were taken against the reagent blank.

\section{Calculation}

Total Protein $(\mathrm{g} / \mathrm{l})=\frac{\text { Absorbance } \mathrm{X} \text { value of standard }}{\text { Absorbance }(\text { Standard })}$

\section{Determination of glucose concentration}

The content of one vial of reagent R1b was reconstituted with a portion of Buffer R1a and the entire contents was transferred to bottle R1, rinsing bottle R1b several times. 500ul of working reagent (R1) was taken in the test tubes labeled as blank. 5ul of the sample was added to $500 \mathrm{ul}$ of the working reagent in the test tubes. The content of the test tubes were mixed and incubated for $10 \mathrm{~min}$ utes at $37^{\circ} \mathrm{C}$ after which $2 \mathrm{ml}$ of the distilled water was added. The samples were transferred from the test tubes into the cuvette and placed in the lab tech auto colorimeter set at $500 \mathrm{~nm}$ and the absorbance readings were taken against the reagent blank.

\section{Calculation Absorbance of sample X \\ Glucose Concentration $(\mathrm{mg} / \mathrm{dl})=\frac{\text { Standard Concentration }}{\text { Absorbance of Standard }}$}

\section{Assessment of nutritional status}

The Nutritional Status of the bread was determined using the protein Efficiency Ratio (PER). This was mathematically calculated using the recommendation of [16]. 
PER =

Weight gain

Total amount of protein $(\mathrm{g})$ in total food intake $(\mathrm{g})$

Blend formulation of wheat and cassava flours

Two flour blends, each containing wheat and cassava flour were prepared by mixing flours in the proportion of 90:10 (B). The control sample was $100 \%$ wheat flour (A). The two samples were packaged in black low density polyethylene bags and stored at room temperature until use for analyses and bread production.

\section{Cassava flour preparation}

Cassava flour was prepared according to the method described by [17] as shown in Figure 1.

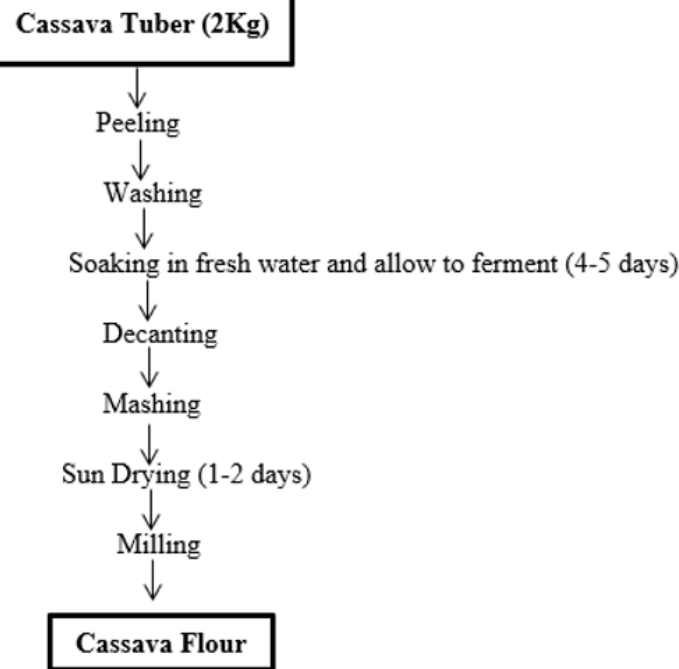

Figure 1: Flow Chart of Cassava Flour Processing. Source: [17] Modified.

\section{Baking process}

The two blends of composite flour were baked into bread using the modified method of ochelle., et al. [10] The wheat flour and composite flour were mixed with $5 \mathrm{~g}$ salt, $10 \mathrm{~g}$ yeast, $7 \mathrm{~g}$ sugar in $250 \mathrm{ml}$ water followed by manual mixing for $5 \mathrm{~min}$ to obtain a dough. The dough was kneaded for some minutes. The kneaded dough was transferred into the baking pans greased with plasticized fat and covered with basins. The dough was allowed to ferment for 35 mins at room temperature in the baking pans. The fer- mented dough was then allowed to undergo proofing for 25 mins at relative humidity. The bread were cooled to room temperature and used for analyses.

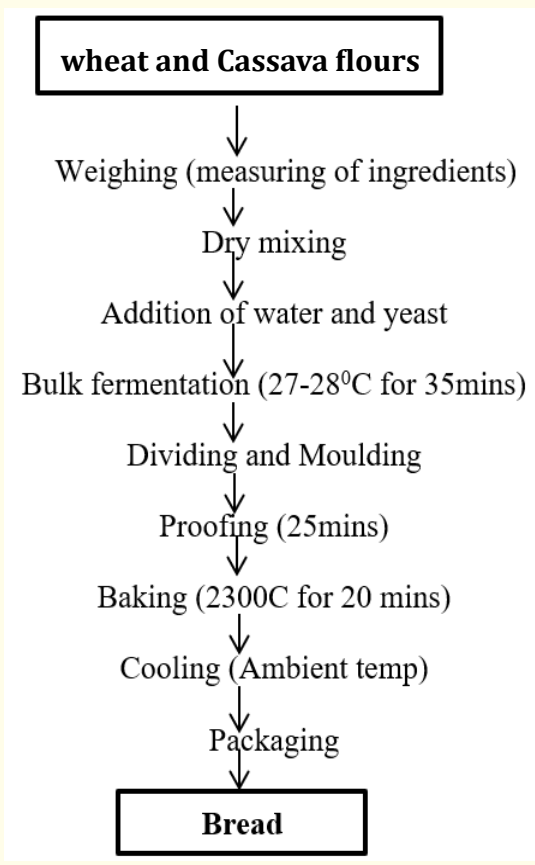

Figure 2: Flow chart for composite bread production.

Source: Ochelle et al. [10] modified.

Table 1: Consumption pattern of Rats Fed on $100 \%$ wheat bread and $90: 10 \%$ wheat and cassava bread.

\begin{tabular}{|l|c|c|}
\hline \multirow{2}{*}{ Study period (days) } & \multicolumn{2}{|c|}{ Food consumed (g) } \\
\cline { 2 - 3 } & A-Group & B-Group \\
\hline Exp1 & $6.73 \pm 1.50^{\mathrm{a}}$ & $4.88 \pm 0.66^{\mathrm{a}}$ \\
\hline Exp2 & $6.10 \pm 1.28^{\mathrm{a}}$ & $5.32 \pm 0.78^{\mathrm{a}}$ \\
\hline ExpT & $6.42 \pm 1.39^{\mathrm{a}}$ & $5.10 \pm 0.72^{\mathrm{a}}$ \\
\hline
\end{tabular}

\section{Keys:}

Exp1: Indicate 1st experiment, Exp 2 indicate 2nd experiment and ExpT indicate total experiment. The numbers of days in each experiment were 7 and 14 respectively

Values are means \pm standard deviation of duplicate determinations; Means with same superscript down the column are not significantly $(\mathrm{P} \geq 0.05)$ different Keys: $\mathrm{A}=$ Rats fed on $(100 \%$ wheat flour control), B = Rat fed on $(90 \%$ wheat flour and $10 \%$ cassava flour). 


\section{Results and Discussion}

Table 2: Weight gain of Rats Fed on 100\% wheat bread and 90:10 wheat-cassava bread.

\begin{tabular}{|l|c|c|}
\hline \multirow{2}{*}{\begin{tabular}{c}
\multirow{2}{*}{$\begin{array}{c}\text { Study period } \\
\text { (days) }\end{array}$} \\
\cline { 2 - 3 }
\end{tabular}} & \multicolumn{2}{c|}{ Weight gained (g) } \\
\hline Exp1 & $3.52 \pm 1.50^{\mathrm{a}}$ & $2.01 \pm 0.94^{\mathrm{a}}$ \\
\hline Exp2 & $2.16 \pm 1.28^{\mathrm{a}}$ & $4.11 \pm 1.05^{\mathrm{a}}$ \\
\hline ExpT & $2.84 \pm 1.39^{\mathrm{a}}$ & $3.06 \pm 1.00^{\mathrm{a}}$ \\
\hline
\end{tabular}

Exp1: Indicate $1^{\text {st }}$ experiment, Exp 2 indicate $2^{\text {nd }}$ experiment and ExpT indicate total experiment. The numbers of days in each experiment were 7 and 14 respectively

$\mathrm{A}=$ Rat weight on (100\% wheat flour control), B = Rat weight on ( $90 \%$ wheat flour and $10 \%$ cassava flour).

Values are means \pm standard deviation of duplicate determinations; Means with same superscript down the column are not significantly $(\mathrm{P} \geq 0.05)$ different

Table 3: Nutritional Quality of 100\% wheat bread and 90:10 wheat-cassava bread

\begin{tabular}{|l|c|c|}
\hline \multirow{2}{*}{ Study period (days) } & \multicolumn{2}{|c|}{ Protein Efficiency Ratio (PER) } \\
\cline { 2 - 3 } & A-Group & B-Group \\
\hline Exp1 & $5.62 \pm 2.86^{\mathrm{a}}$ & $8.68 \pm 3.55^{\mathrm{a}}$ \\
\hline Exp2 & $2.62 \pm 9.09^{\mathrm{b}}$ & $16.36 \pm 3.85^{\mathrm{a}}$ \\
\hline ExpT & $4.47 \pm 4.25^{\mathrm{a}}$ & $12.73 \pm 3.28^{\mathrm{a}}$ \\
\hline
\end{tabular}

\section{Keys:}

Exp1: Indicate $1^{\text {st }}$ experiment, Exp 2 indicate $2^{\text {nd }}$ experiment and ExpT indicate total experiment. The numbers of days in each experiment were 7 and 14 respectively

$\mathrm{A}=$ PER of Rat on (100\% wheat flour control), B =PER of Rat fed on (90\% wheat flour and $10 \%$ cassava flour).

Values are means \pm standard deviation of duplicate determinations.

Means with same superscript down the column are not significantly $(\mathrm{P} \geq 0.05)$ different
Table 4: Total Protein in Blood of Rats fed with 100\% wheat bread and 90:10\% wheat-cassava composite bread.

\begin{tabular}{|l|c|c|}
\hline \multirow{2}{*}{ Study period (days) } & \multicolumn{2}{|c|}{ Total Protein (g/l) } \\
\cline { 2 - 3 } & A-Group & B-Group \\
\hline Accl & $18.60 \pm 9.24^{\mathrm{b}}$ & $23.50 \pm 9.08^{\mathrm{b}}$ \\
\hline Exp1 & $93.83 \pm 31.32^{\mathrm{b}}$ & $25.91 \pm 5.89^{\mathrm{a}}$ \\
\hline Exp2 & $68.77 \pm 44.41^{\mathrm{b}}$ & $77.90 \pm 35.39^{\mathrm{b}}$ \\
\hline ExpT & $60.40 \pm 28.32^{\mathrm{b}}$ & $42.44 \pm 16.79^{\mathrm{b}}$ \\
\hline
\end{tabular}

\section{Keys:}

Accl: Acclimatization

Exp1: Indicate $1^{\text {st }}$ experiment, Exp 2 indicate $2^{\text {nd }}$ experiment and ExpT indicate total experiment. The numbers of days in each experiment were 7 and 14 respectively

$A=(100 \%$ wheat flour control $), B=(90 \%$ wheat flour and $10 \%$ cassava flour).

Values are means \pm standard deviation of duplicate determinations. Means with same superscript down the column are not significantly $(\mathrm{P} \geq 0.05)$ different

Table 5: Plasma Glucose Concentration of Rats fed with 100\% wheat bread and 90:10\% wheat-cassava composite bread.

\begin{tabular}{|l|c|c|}
\hline \multirow{2}{*}{ Study period (days) } & \multicolumn{2}{|c|}{ Plasma Glucose (g/l) } \\
\cline { 2 - 3 } & A-Group & B-Group \\
\hline Accl & $0.82 \pm 0.40^{\mathrm{a}}$ & $0.58 \pm 0.15^{\mathrm{a}}$ \\
\hline Exp1 & $1.72 \pm 0.43^{\mathrm{a}}$ & $1.54 \pm 0.41^{\mathrm{a}}$ \\
\hline Exp2 & $4.09 \pm 2.27^{\mathrm{a}}$ & $6.44 \pm 2.02^{\mathrm{a}}$ \\
\hline ExpT & $2.21 \pm 1.03^{\mathrm{a}}$ & $2.85 \pm 0.86^{\mathrm{a}}$ \\
\hline
\end{tabular}

Key:

Accl: Acclimatization; $A=(100 \%$ wheat flour control $), B=(90 \%$ wheat flour and $10 \%$ cassava flour).

Exp1: Indicate $1^{\text {st }}$ experiment, Exp 2 indicate $2^{\text {nd }}$ experiment and ExpT indicate total experiment. The numbers of days in each experiment were 7 and 14 respectively

Values are means \pm standard deviation of duplicate determinations. Means with same superscript down the column are not significantly $(\mathrm{P} \geq 0.05)$ different: 
Results of the consumption pattern of Rats Fed on $100 \%$ wheat bread and 90:10\% wheat and cassava bread is presented in Table 1. Results indicate that rats in the A-group consumed more of the food (6.42) than those in B-group (5.10). This could be due to the fact that the bread was processed from $100 \%$ wheat flour which had pleasant flavour and texture [6].

Weight gain of Rats Fed on 100\% wheat bread and 90:10 wheat-cassava bread is presented in Table 2, although the rats in the A-group consumed more, those in the B-group had higher mean weight gain (3.06) than those in the A-group (2.84). In the course of the experiment, it was observed that the rats in A-group excreted and passed urine very often. The rats in the A-group ate more, retained less water and excreted more faces whereas those in the B-group ate moderately, retained more and excreted less. This could be reason behind the increasing weight gain of the rats in the B-group when compared to those in the A-group. However, result shows no significant difference.

The Protein efficiency ratio results are presented in Table 3. The rats in the B-group was higher (12.73) than those of the rats in the A-group this was probably due to the increase in weight gain among rats in the B-group. The statistical results indicate that the plasma protein was significantly different among rats in the two groups in the first week of the experimental period.

The mean plasma protein of the rats in group-A was higher (60.40) than those of the B-group (43.44) as presented in Table 4. This could be due to the protein (gluten) present in the wheat flour that was used in processing the $100 \%$ wheat bread, this protein was absent in the composite bread. This indicated that the control diet supported growth more than the composite bread diet.

The plasma glucose level of the rats in the B-group was higher (2.85) than those of the rats in the A-group (2.21) as depicted in Table 5. It was observed that the plasma glucose levels in both groups were increasing as the experimental period progressed. The plasma glucose of normal wistar rats is said to be 3.1 [18]. Hence, it can be said that the rats were hyperglycemic with continuous feeding of the foods. There was no significant difference between their mean (2.53). It can be concluded that the rats in the B-group had higher plasma glucose and so could be supporting the effect of overweight as an associated risk for diabetes in an overfed population [19].

\section{Conclusion}

Results revealed that the weight gain, protein efficiency ratio and plasma glucose of the 90:10 wheat and cassava bread were not significantly different from that of the $100 \%$ wheat bread. Result of the plasma glucose also showed that both the $100 \%$ wheat bread and the cassava composite bread were above the normal plasma glucose level, continuous feeding on the bread alone could lead to hyperglycemia. It is recommended that, further study be carried out to investigate the rapid weight gain of rats that fed on the cassava composite bread. The plasma protein of the rats fed on the composite bread was seen to be below the normal plasma protein. It is therefore recommended that, bakeries should include protein supplement in the processing of cassava composite bread.

\section{Bibliography}

1. Dewettinck KB., et al. "Nutritional Value of Bread,influence of processing, food interaction and consumer perception". Journal of Cereal Science 48.2 (2008): 243-257.

2. Abdelghafor., et al. "Quality of Bread from composite flour of sorghum and hard white winter wheat". Advanced Journal of Food Science Technology 3 (2010): 9-15.

3. David MO. Nigeria, No 1 Market for U.S Wheat; potential for other (2006).

4. Shittu TA., et al. "Bread from composite cassava Effect of baking time and temperature on some physical properties of bread loaf". Food Research International 40.2 (2007): 280-290.

5. Oyewole OB., et al. "Production of Biscuit using cassava flour". Nigeria Food Journal 14 (1996): 24-29.

6. Ogunjobi MAK and Ogunwole SO. "Physicochemical and sensory properties of cassava flour Biscuits supplemented with Cashew Apple Powder". Journal of Food Science and Technology (2010).

7. Siddiq M., et al. "Effect of defatted germ flour addition on the physical and sensory quality of wheat bread". Food Science and Technology 42.2 (2009): 464-470.

8. Oladunmoye 00., et al. "Evaluation of some physicochemical properties of wheat, cassava, maize and cowpea flours for bread making". Journal of Food Quality 33.6 (2010): 693-708.

9. Erikson E Koch., et al. "Evaluation of the physical and sensory characteristics of bread from varieties of cassava and wheat composite flour". Food and public Health 4.5 (2014): 214-222.

10. Ochelle PO., et al. "Quality Assessment of Bread from wheat, water yam and Soybean flours". Asian Food Science Journal 10.3 (2019):1-8. 
11. King NLR and Bradbury JH. "Bitterness of cassava: Identification of a new Apiosyl Glycoside and other compounds that affect its Bitter Taste". Journal of the Science of Food and Agriculture 68.2 (1995): 223-230.

12. Berry SA. "Socio-Economic Aspect of Cassava Cultivation and use in Africa: Implication for Development of Appropriate Technology". International Institute of Tropical Agriculture (1993).

13. Bradbury JH and Holloway WD. "Chemistry of Tropical Root Crops: Significance for Nutrition and Agriculture in the specific". Australian Centre for International Agricultural Research Monograph No 6, Canberra, Australia (1998).

14. Nweke FI., et al. The cassava Transformation. University Press, Michigan State, USA (2002).

15. Chibuzo SP. Bread making: an overview in S.P cauvain (eds). Woodhead Publishing Limited, England (2007).

16. AOAC. "Official method of Analysis 14th Edition". Association of Official Analytical Chemist. Washington DC (1984).

17. Nambisan B. "Strategies for elimination of cyanogens from cassava for reducing toxicity and improving food safety". Food Chemistry Toxicol 49.3 (2011): 690-693.

18. Issasson G., et al. "Effect of pectin on Glycaemia and Insulinaemia after starch loading in normal, Allpxan Diabetic and Pancreatic Duct-Occluded Rats". Acta Endocrinologica 103 (1983): 376-384.

19. Feskens EJ. "Role of Nutrition in the development of type 11 Diabetics and Glucose Intolerance; possibilities for prevention (in Dutch)". Ned Tijdchr Geneeskd 136 (1992): 1701-1706.

Volume 2 Issue 10 October 2019

(c) All rights are reserved by Ameh., et al. 